\title{
Altered surface hydrology as a potential mechanism for subsidence in coastal Louisiana
}

\author{
Jaap H. Nienhuis ${ }^{1}$, Torbjörn E. Törnqvist ${ }^{2}$, and Gilles Erkens ${ }^{1,3}$ \\ ${ }^{1}$ Department of Physical Geography, Utrecht University, Utrecht, the Netherlands \\ ${ }^{2}$ Department of Earth and Environment Sciences, Tulane University, New Orleans, LA, USA \\ ${ }^{3}$ Department of Subsurface and Groundwater Systems, Deltares, Utrecht, the Netherlands \\ Correspondence: Jaap H. Nienhuis (j.h.nienhuis@uu.nl) \\ Published: 22 April 2020
}

\begin{abstract}
The natural wetlands of coastal Louisiana are experiencing rapid subsidence rates averaging $9 \pm$ $1 \mathrm{~mm} \mathrm{yr}^{-1}$. Recent measurements based on GPS data and CRMS surface elevation tables (SETs) have shown that most of the subsidence is shallow and occurs in the uppermost 5 meters. Sources of subsidence and the origin of their spatial variability are strongly debated. Here we use CRMS SETs together with historic maps of coastal Louisiana to explore two hypotheses: (i) shallow subsidence is a result of accommodation created by (long-term) deep subsidence processes and self-weight consolidation, and (ii) changes in marsh hydrology (groundwater and surface water flows) have led to a recent increase in shallow subsidence.

First, we find that, although self-weight consolidation would result in generally high observed shallow subsidence rates, it does not explain the rates nor the spatial variability of the CRMS SET data. Second, based on historic maps, we find that shallow subsidence rates are significantly higher for CRMS sites where shipping canals have reduced their distance to the marsh edge. This is potentially a result from increased sediment deposition, but CRMS data also show altered groundwater levels near the marsh edge. We find some indication that prolonged periods of low water could have led to increases in effective stresses that explain some of the rapid rates of shallow subsidence observed along Louisiana's coastline.
\end{abstract}

\section{Introduction}

Many low-lying coastal areas including coastal Louisiana experience elevated rates of relative sea-level rise because of subsidence (Jankowski et al., 2017; Minderhoud et al., 2018; Nienhuis et al., 2017; Teatini et al., 2011). Recent data collection through the Coastal Reference Monitoring System (Steyer et al., 2003; https://lacoast.gov/crms/, last access: 1 August 2019) (Fig. 1a) has allowed for unprecedented analyses of subsidence rates and patterns in coastal Louisiana (e.g., Jankowski et al., 2017; Nienhuis et al., 2017; Sanks et al., 2019), but subsidence mechanisms are still poorly understood. Subsidence at depth is likely a combination of isostasy and fault movement (Frederick et al., 2019), but tends to be much slower compared to subsidence observed at the surface (Frederick et al., 2019; Wolstencroft et al., 2014). For shallow subsidence, several mechanisms have been proposed, including shallow hydrological modifications such as weirs and impoundments (Turner, 2004), soil consolidation resulting from sediment deposition (Törnqvist et al., 2008), with (Meckel et al., 2006) or without (Jankowski et al., 2017) a relation to Holocene sediment thickness.

Here we analyze the CRMS dataset (Fig. 1) to better understand shallow subsidence. CRMS subsidence measurements are obtained based on surface elevation change and vertical accretion data of surface elevation tables (SET's) (Fig. 1b). Jankowski et al. (2017) compiled these data and included deep subsidence from GPS measurements (Karegar et al., 2015) to investigate decadal-timescale subsidence. We use the data of Jankowski et al. (2017), together with CRMS water level and soil property data (Steyer et al., 2003). We use digitized land loss maps of Penland et al. (2000) instead of more recent land loss maps (e.g., Couvillion et al., 2017) because it is vectorized and because it includes a description of the type of wetland loss (e.g. interior canals vs. shoreline 


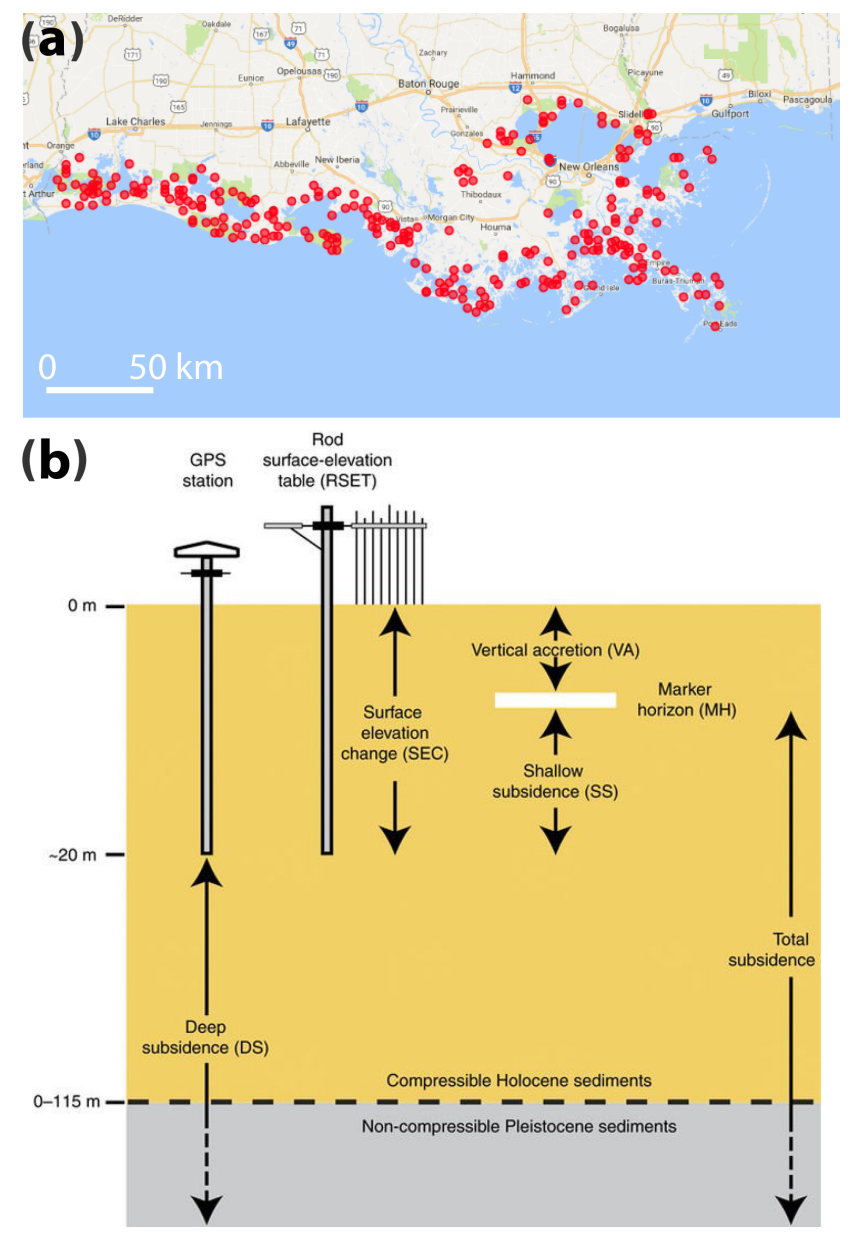

Figure 1. (a) Location of CRMS stations used to determine subsidence rates, at 274 sites along the Louisiana coast, based on data collected through the Coastwide Reference Monitoring System (CRMS) program. (b) Schematic of a CRMS-SET, including indicated range of deep subsidence (DS) and shallow subsidence (SS), reproduced from Jankowski et al. (2017).

erosion). We investigate two hypotheses: (1) shallow subsidence is caused by self-weight consolidation, and (2) shallow subsidence is caused by surficial hydrological change.

\section{Self-weight consolidation}

Self-weight (primary) consolidation implies that the weight of accreted sediment expels pore-water fluid from underlying layers, forcing their consolidation. Self-weight consolidation can potentially create high surface subsidence rate (Teatini et al., 2011; Törnqvist et al., 2008; Tovey and Paul, 2002; Zoccarato et al., 2018). However, accommodation space must be created by deep subsidence processes for these rates to be sustained on long timescales.

Here we perform a simple analysis to investigate the potential rate of self-weight-consolidation-driven subsidence. We solve the following implicit function (Tovey and Paul,
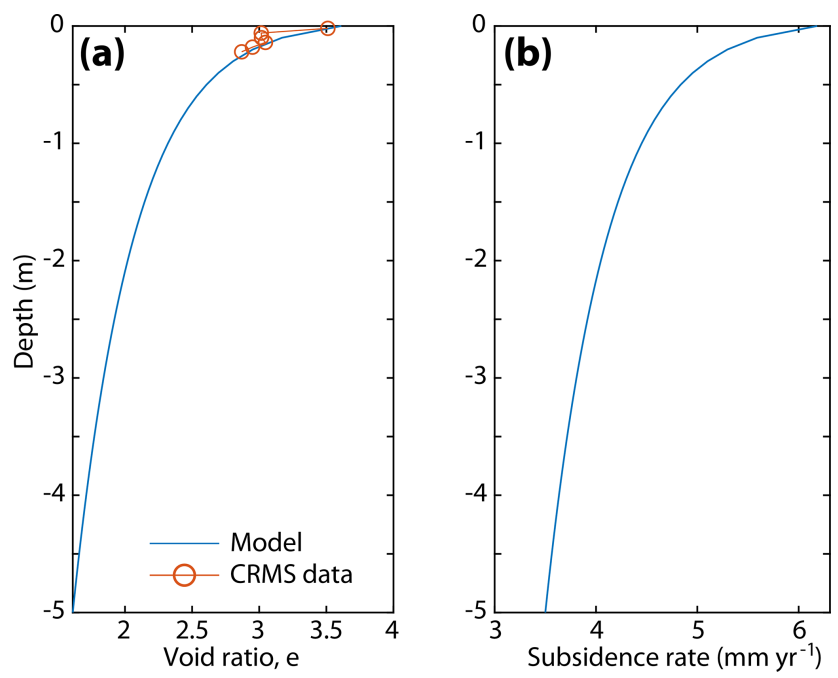

Figure 2. Equilibrium depth dependence of the (a) void ratio, assuming sediment deposition with a void ratio of 3.5 , and (b) subsidence rate (SS + DS), assuming mass-balance and a DS (deep subsidence) rate of $3 \mathrm{~mm} \mathrm{yr}^{-1}$ at a depth of $10 \mathrm{~m}$. CRMS data show the average void ratio across all CRMS sites.

2002), which describes the void ratio $e$ as a function of depth $z(\mathrm{~m})$,

$e(z)=e_{0}-c_{\mathrm{c}} \log _{10}\left(\sigma_{0}+\sigma^{\prime}(z)\right)$,

with the added weight of overlying sediments $\left(\mathrm{kN} \mathrm{m}^{-2}\right)$,

$\sigma^{\prime}(z)=\gamma_{\mathrm{w}} \int_{0}^{z} \frac{G_{\mathrm{s}}+e(z)}{1+e(z)} \mathrm{d} z$,

where $e_{0}$ is the void ratio of the deposited sediment at $z=0$, $\gamma_{\mathrm{w}}$ is the specific weight of water $\left(\sim 9.8 \mathrm{kN} \mathrm{m}^{-3}\right), G_{\mathrm{s}}$ is the specific gravity of the sediments $(\sim 2.6), c_{\mathrm{c}}$ is a consolidation coefficient (here $\sim 1$ ), and $\sigma_{0}$ is a reference weight (here $\sim$ $0.1 \mathrm{kN} \mathrm{m}^{-2}$ ).

Based on CRMS soil data of the upper $0.24 \mathrm{~m}$ of the marsh surface and a void ratio of the deposited sediment of $e_{0}$ of 3.5 , we obtain an approximate equilibrium void ratio distribution (Fig. 2a). The void ratio distribution also determines the equilibrium shallow subsidence rate (SS, $\mathrm{mm} \mathrm{yr}^{-1}$ ) at depth (z) via mass-balance and the creation of accommodation. The void ratio distribution implies a linear relationship between deep (DS) and shallow (SS) subsidence rates,

$\mathrm{SS}(z)=\operatorname{DS}\left(\frac{e(z)+1}{e_{\mathrm{DS}}+1}-1\right)$,

where $e_{\mathrm{DS}}$ is the void ratio at depth (Fig. 2b).

We apply Eq. (2) and estimate shallow subsidence rates for every CRMS site based on local deep subsidence rates, depth of the deep subsidence measurement, and local surface void ratio (Fig. 3). We find that Eq. (2) underpredicts subsidence rates and also does not explain the variability in the 


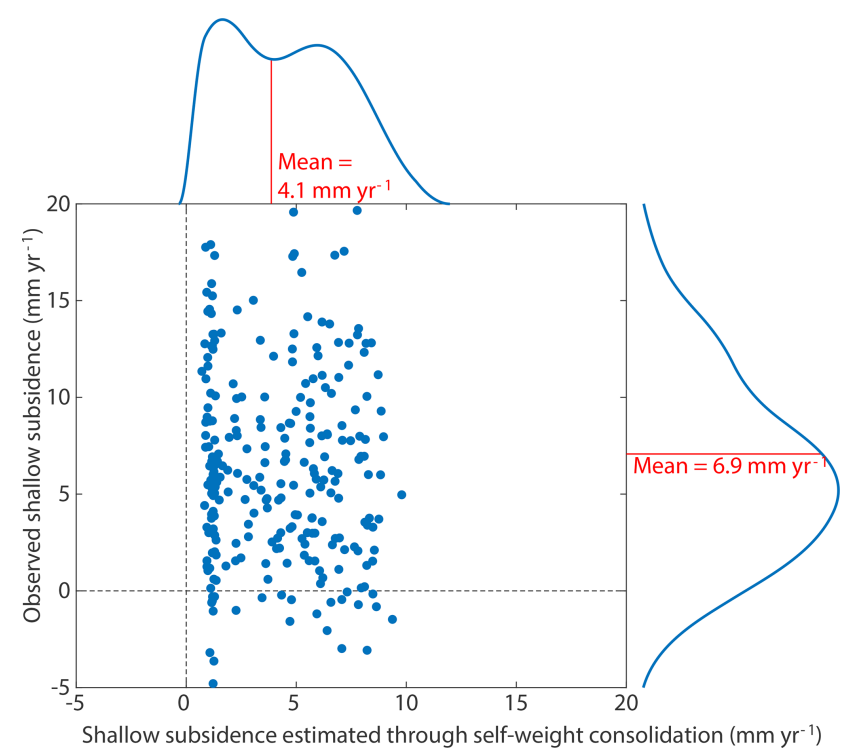

Figure 3. Estimated vs. predicted shallow subsidence based on Eq. (2). Histograms show distribution of predicted and observed rates, including their mean.

observed shallow subsidence rates. We do not find a correlation between the deep subsidence and shallow subsidence rates.

\section{Altered surface hydrology}

We explore the hypothesis that changes in horizontal surface hydrology affect shallow subsidence rates in coastal Louisiana. This hypothesis was raised by Turner (2004), who suggested that prolonged wet and dry periods in marshes after the creation of canals and adjacent spoil banks through marshes could lead to increased subsidence. Studies of other marshes have also found that changing surface water (and adjacent ground water) affects subsidence rates, even for cases where surface water changes occur over relatively short periods of weeks/months (Deverel and Leighton, 2010) or days (Chai et al., 2017). Note that marsh groundwater changes strongly depend on the distance to the marsh edge. Eco-hydrological models of salt marshes generally find that groundwater change is limited to places near edges (Montalto et al., 2007; Ursino et al., 2004) but that the length scale depends on the period of water level fluctuations (Moffett et al., 2012). Interiors are determined by vertical processes, or horizontal processes driven by differences in vegetation, transpiration in the case of non-flooding tides (Moffett et al., 2012).

\subsection{Distance from CRMS sites to marsh edge}

To explore our hypothesis, we first investigate hydrological changes to Louisiana marshes. We do not use a hydrological

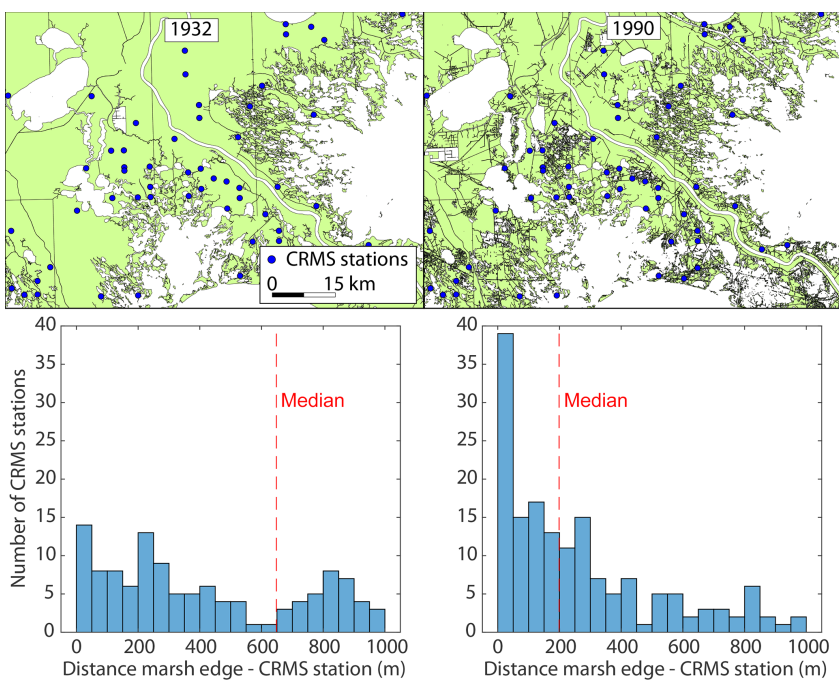

Figure 4. MRD land area map for 1932 and 1990, based on Penland et al. (2000), including CRMS stations, and average distance of CRMS stations to the marsh edge.

model, rather we investigate land loss maps and assume that the distance to the nearest open water can serve as a proxy for marsh hydrology. Based on digitized land loss maps between 1932 and 1990 (Penland et al., 2000), we find that the median distance from CRMS sites to open water has been reduced considerably (Fig. 5). Of the 168 CRMS sites for which we have data, 73 have gotten closer to open water because of the construction of a canal, 21 have gotten closer because of other types of land loss, and 74 have not seen the distance to the marsh edge reduced. Note that these distances should be considered maximum possible distances given the lowresolution digital maps that tend to miss small water bodies including narrow canals.

\subsection{Effect of canals on shallow subsidence}

Using the CRMS data together with land loss maps, we next investigate the relationship between shallow subsidence and local hydrology. We do not find a significant relationship between the distance to the marsh edge and shallow subsidence. However, we do find statistically significantly higher shallow subsidence rates in CRMS sites where the distance to the marsh edge has decreased between 1932 and 1990 (Fig. 5a). Mean shallow subsidence in sites with equal distance to open water is $6 \pm 1 \mathrm{~mm} \mathrm{yr}^{-1}(n=95)$, compared to $9 \pm 1 \mathrm{~mm} \mathrm{yr}^{-1}$ $(n=73)$ for sites which have gotten closer to open water because a canal had been constructed.

Next, we explore potential causes for increased shallow subsidence rates. It is likely that these sites experience increased vertical accretion of sediment because of their proximity to canals or other water bodies that carry suspended sediment when the marsh floods (Reed et al., 1999). Sediment accretion would then result in higher soil stresses and 

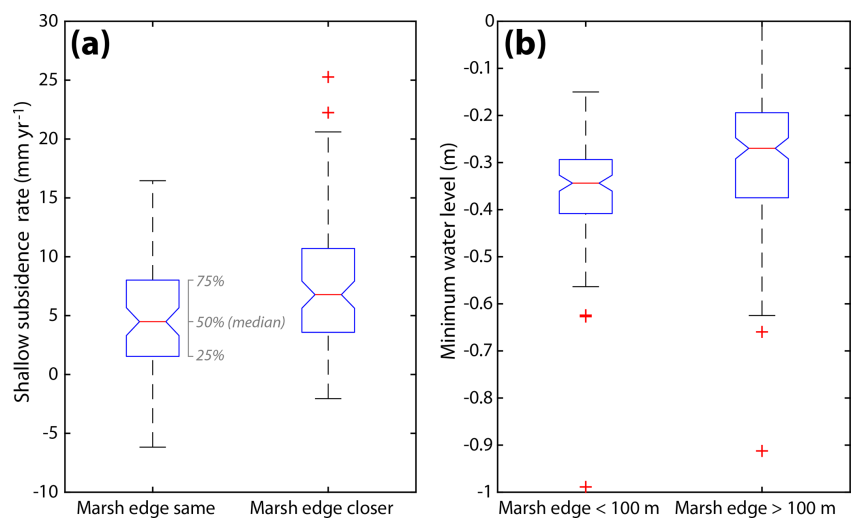

Figure 5. (a) Distribution of shallow subsidence rates for locations where a shipping canal has (not) reduced the distance to the marsh edge. (b) Distribution of minimum water level for sites within and outside of $100 \mathrm{~m}$ from the marsh edge.

associated soil consolidation. Unfortunately, our subsidence rates are derived based on the difference between vertical accretion (sedimentation) and surface elevation change. We do not have independent sedimentation data for these CRMS sites, making us unable to further explore the relation between subsidence and sedimentation.

Second, reduced distance to open water could also potentially lower marsh groundwater and result in increased effective stress and soil consolidation. Regular (micro-tidal) surface water changes only affect water tables for a very limited distance into the marsh (Montalto et al., 2007). However, we find that surface and groundwater data for many CRMS sites (e.g. site 114, Fig. 6) show significant longer timescale variability. These water table changes are likely to be driven by precipitation, wind (e.g., Valentine and Mariotti, 2019), or other climatic variability. Ground water table fluctuations appear larger for CRMS sites located closer to the marsh edge (Fig. 5b). However, we are not able to directly relate ground water fluctuations to subsidence data because only a few CRMS sites have ground water table data. More data is needed to quantify the potential effect of ground water lowering on shallow subsidence.

Note that canals have been constructed since the 1950s and that CRMS subsidence rates can be considered modern. Any relation between canal construction and subsidence therefore would imply long timescale subsidence.

\section{Conclusions}

We have investigated potential mechanisms for shallow subsidence in coastal Louisiana based on the CRMS data. We find that rapid shallow subsidence is unlikely to be driven by self-weight consolidation in equilibrium with accommodation created from deep subsidence processes. Comparison of patterns of shallow subsidence rates to land loss maps shows that the creation of shipping canals could have in-

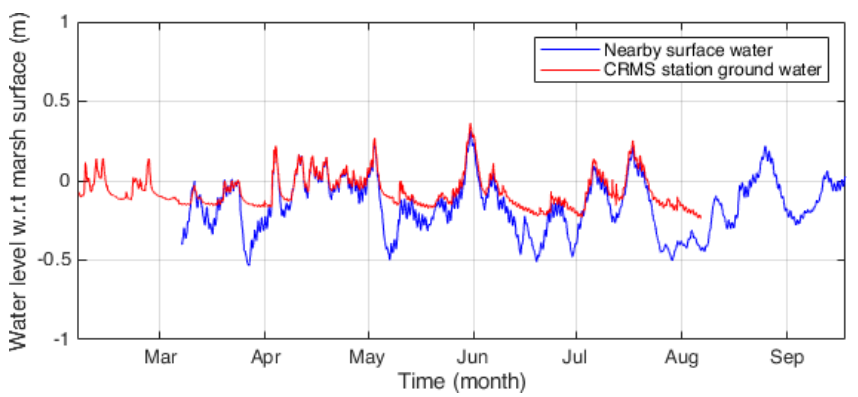

Figure 6. Ground water and surface water levels for CRMS site 114 , located $37 \mathrm{~m}$ from the marsh edge from FebruarySeptember 2013.

creased shallow subsidence in coastal Louisiana, potentially through a combination of increased vertical accretion of sediment and prolonged periods of lowered groundwater tables. Future studies should aim to quantify these trends.

Data availability. All data to reproduce these findings are available online. The subsidence map can be found at: https://osf.io/ m83z4/ (last access: 1 August 2019; Nienhuis et al., 2017). CRMS measurement station data of coastal Louisiana wetland hydrology and soils can be retrieved from: https://lacoast.gov/crms/ (last access: 1 August 2019; Steyer et al., 2003). Land loss maps can be found at: https://pubs.usgs.gov/dds/dds79/HTMLDOCS/catalog. htm (last access: 1 August 2019; Penland et al., 2000).

Author contributions. JHN performed the research and wrote the initial draft of the manuscript. All authors contributed to data interpretation and paper writing.

Competing interests. Gilles Erkens is member of the editorial board of this special issue but has not reviewed this paper, nor has he influenced the publication decision process.

Special issue statement. This article is part of the special issue "TISOLS: the Tenth International Symposium On Land Subsidence - living with subsidence". It is a result of the Tenth International Symposium on Land Subsidence, Delft, the Netherlands, 17-21 May 2021.

Acknowledgements. Data collection efforts are funded through the Coastal Wetland Planning, Protection, and Restoration Act (CWPPRA) Program and the State of Louisiana to support the Coastwide Reference Monitoring System (CRMS). The Coastal Protection and Restoration Authority of Louisiana and the United States Geological Survey jointly implement the CRMS Program on behalf of CWPPRA. 
Financial support. This research has been supported by the National Science Foundation, Division of Earth Sciences (grant no. 1810855) and the NWO (grant no. vi.veni.192.123).

\section{References}

Chai, J., Suddeepong, A., Liu, M. D., and Yuan, D.-J.: Effect of Daily Fluctuation of Groundwater Level on Land-Subsidence, Int. J. Geosynth. Gr. Eng., 3, 1-10, https://doi.org/10.1007/s40891-016-0079-x, 2017.

Couvillion, B. R., Beck, H., Schoolmaster, D., and Fischer, M.: Land Area Change in Coastal Louisiana (1932 to 2016), U.S. Geological Survey, Washington DC, https://doi.org/10.3133/sim3381, 2017.

Deverel, S. J. and Leighton, D. A.: Historic, Recent, and Future Subsidence, Sacramento-San Joaquin Delta, California, USA, San Fr., Estuary Watershed Sci., 8, 1-6, https://doi.org/10.15447/sfews.2010v8iss2art1, 2010.

Frederick, B. C., Blum, M., Fillon, R., and Roberts, H.: Resolving the contributing factors to Mississippi Delta subsidence: Past and Present, Basin Res., 31, 171-190, https://doi.org/10.1111/bre.12314, 2019.

Jankowski, K. L., Törnqvist, T. E., and Fernandes, A. M.: Vulnerability of Louisiana's coastal wetlands to present-day rates of relative sea-level rise, Nat. Commun., 8, 14792, https://doi.org/10.1038/ncomms14792, 2017.

Karegar, M. A., Dixon, T. H., and Malservisi, R.: A threedimensional surface velocity field for the Mississippi Delta: Implications for coastal restoration and flood potential, Geology, 43, 519-522, https://doi.org/10.1130/G36598.1, 2015.

Meckel, T. A., ten Brink, U. S., and Williams, S. J.: Current subsidence rates due to compaction of Holocene sediments in southern Louisiana, Geophys. Res. Lett., 33, 1-5, https://doi.org/10.1029/2006GL026300, 2006.

Minderhoud, P. S. J. S. J., Coumou, L., Erban, L. E. E., Middelkoop, H., Stouthamer, E., and Addink, E. A. A.: The relation between land use and subsidence in the Vietnamese Mekong delta, Sci. Total Environ., 634, 715-726, https://doi.org/10.1016/j.scitotenv.2018.03.372, 2018.

Moffett, K. B., Gorelick, S. M., McLaren, R. G., and Sudicky, E. A.: Salt marsh ecohydrological zonation due to heterogeneous vegetation-groundwater-surface water interactions, Water Resour. Res., 48, https://doi.org/10.1029/2011WR010874, 2012.

Montalto, F. A., Parlange, J. Y., and Steenhuis, T. S.: A simple model for predicting water table fluctuations in a tidal marsh, Water Resour. Res., 43, 1-22, https://doi.org/10.1029/2004WR003913, 2007.

Nienhuis, J. H., Törnqvist, T. E., Jankowski, K. L., Fernandes, A. M., and Keogh, M. E.: A New Subsidence Map for Coastal Louisiana, GSA Today, 27, 60-61, https://doi.org/10.1130/GSATG337GW.1, 2017 (data available at: https://osf.io/m83z4/, last access: 1 August 2019).
Penland, S., Wayne, L., Britsch, L. D., Williams, S. J., Beall, A. D., and Butterworth, V. C.: Geomorphic classification of coastal land loss between 1932 and 1990 in the Mississippi River delta plain, southeastern Louisiana (open file report 00-417), U.S. Geological Survey, Washington DC, USA, https://doi.org/10.3133/ofr00417, 2000 (data available at: https:// pubs.usgs.gov/dds/dds79/HTMLDOCS/catalog.htm, last access: 1 August 2019).

Reed, D. J., Spencer, T., Murray, A. L., French, J. R., and Leonard, L.: Marsh surface sediment deposition and the role of tidal creeks: Implications for created and managed coastal marshes, J. Coast. Conserv., 5, 81-90, https://doi.org/10.1007/BF02802742, 1999.

Sanks, K. M., Shaw, J. B., and Naithani, K. J.: Field-Based Estimate of the Sediment Deficit in Louisiana, OSF Prepr., https://doi.org/10.31219/osf.io/vp5j7, 2019.

Steyer, G. D., Sasser, C. E., Visser, J. M., Swenson, E. M., Nyman, J. A., and Raynie, R. C.: A Proposed Coast-Wide Reference Monitoring System for Evaluating Wetland Restoration Trajectories in Louisiana, Environ. Monit. Assess., 81, 107-117, https://doi.org/10.1023/A:1021368722681, 2003 (data available at: https://lacoast.gov/crms/, last access: 1 August 2019).

Teatini, P., Tosi, L., and Strozzi, T.: Quantitative evidence that compaction of Holocene sediments drives the present land subsidence of the Po Delta, Italy, J. Geophys. Res., 116, B08407, https://doi.org/10.1029/2010JB008122, 2011.

Törnqvist, T. E., Wallace, D. J., Storms, J. E. A., Wallinga, J., van Dam, R. L., Blaauw, M., Derksen, M. S., Klerks, C. J. W., Meijneken, C., and Snijders, E. M. A.: Mississippi Delta subsidence primarily caused by compaction of Holocene strata, Nat. Geosci., 1, 173-176, https://doi.org/10.1038/ngeo129, 2008.

Tovey, K. N. and Paul, M. A.: Modelling self-weight consolidation in Holocene sediments, B. Eng. Geol. Environ., 61, 21-33, https://doi.org/10.1007/s100640100126, 2002.

Turner, R. E.: Coastal wetland subsidence arising from local hydrologic manipulations, Estuaries, 27, 265-272, 2004.

Ursino, N., Silvestri, S., and Marani, M.: Subsurface flow and vegetation patterns in tidal environments, Water Resour. Res., 40, 1-11, https://doi.org/10.1029/2003WR002702, 2004.

Valentine, K. and Mariotti, G.: Wind-driven water level fluctuations drive marsh edge erosion variability in microtidal coastal bays, Cont. Shelf Res., 176, 76-89, https://doi.org/10.1016/j.csr.2019.03.002, 2019.

Wolstencroft, M., Shen, Z., Törnqvist, T. E., Milne, G. A., and Kulp, M.: Understanding subsidence in the Mississippi Delta region due to sediment, ice, and ocean loading: Insights from geophysical modeling, J. Geophys. Res.-Sol. Ea., 119, 3838-3856, https://doi.org/10.1002/2013JB010928, 2014.

Zoccarato, C., Minderhoud, P. S. J., and Teatini, P.: The role of sedimentation and natural compaction in a prograding delta: insights from the mega Mekong delta, Vietnam, Sci. Rep.-UK, 8, 11437, https://doi.org/10.1038/s41598-018-29734-7, 2018. 